\title{
Voltage-gated and ATP-sensitive $\mathrm{K}^{+}$channels are associated with cell proliferation and tumorigenesis of human glioma
}

\author{
QIN RU $^{1,2}$, XIANG TIAN ${ }^{1,2}$, YU-XIANG WU $^{1}$, RI-HUI WU ${ }^{1}$, MING-SHAN PI $^{1}$ and CHAO-YING LI ${ }^{1,2}$ \\ ${ }^{1}$ Wuhan Institutes of Biomedical Sciences, Jianghan University, Wuhan, Hubei 430056; \\ ${ }^{2}$ HuaWind Health, Inc., Wuhan East Lake High-Technological Development Zone, Wuhan, Hubei 430075, P.R. China
}

Received September 17, 2013; Accepted November 1, 2013

DOI: 10.3892/or.2013.2875

\begin{abstract}
Increasing evidence indicates that potassium $\left(\mathrm{K}^{+}\right)$ channels play important roles in the growth and development of human cancer. In the present study, we investigated the contribution of and the mechanism by which $\mathrm{K}^{+}$channels control the proliferation and tumor development of U87-MG human glioma cells. A variety of $\mathrm{K}^{+}$channel blockers and openers were used to differentiate the critical subtype of $\mathrm{K}^{+}$ channels involved. The in vitro data demonstrated that selective blockers of voltage-gated $\mathrm{K}^{+}\left(\mathrm{K}_{\mathrm{V}}\right)$ channels or ATP-sensitive $\mathrm{K}^{+}\left(\mathrm{K}_{\mathrm{ATP}}\right)$ channels significantly inhibited the proliferation of U87-MG cells, blocked the cell cycle at the $\mathrm{G}_{0} / \mathrm{G}_{1}$ phase and induced apoptosis. In the U87-MG xenograft model in nude mice, $\mathrm{K}_{\mathrm{V}}$ or $\mathrm{K}_{\mathrm{ATP}}$ channel blockers markedly suppressed tumor growth in vivo. Furthermore, electrophysiological results showed that $\mathrm{K}_{\mathrm{V}}$ or $\mathrm{K}_{\mathrm{ATP}}$ channel blockers inhibited $\mathrm{K}_{\mathrm{V}} / \mathrm{K}_{\text {ATP }}$ channel currents as well as cell proliferation and tumor growth over the same concentration range. In contrast, iberiotoxin, a selective blocker of calcium-activated $\mathrm{K}^{+}$channels, had no apparent effect on the cell proliferation, cell cycle or apoptosis of U87-MG cells. In addition, the results of fluorescence assays indicated that blockers of $\mathrm{K}_{\mathrm{V}}$ or $\mathrm{K}_{\mathrm{ATP}}$ channels attenuated intracellular $\mathrm{Ca}^{2+}$ signaling by blocking $\mathrm{Ca}^{2+}$ influx in U87-MG cells. Taken together, these data suggest that $\mathrm{K}_{\mathrm{V}}$ and $\mathrm{K}_{\mathrm{ATP}}$ channels play important roles in the proliferation of U87-MG cells and that the influence of $\mathrm{K}_{\mathrm{V}}$ and $\mathrm{K}_{\text {ATP }}$ channels may be mediated by a $\mathrm{Ca}^{2+}$-dependent mechanism.
\end{abstract}

\section{Introduction}

Gliomas are the most common malignant brain tumors and are characterized by relentless growth and aggressive invasion

Correspondence to: Professor Chao-Ying Li, Wuhan Institutes of Biomedical Sciences, Jianghan University, Wuhan Economic and Technological Development Zone, Wuhan, Hubei 430056, P.R. China

E-mail: licy.whibs.corresp@gmail.com

Key words: potassium channels, glioma, cell proliferation, $\mathrm{Ca}^{2+}$ influx into the brain parenchyma (1). Under the current standard of care, the life expectancy of patients with glioma is $\sim 14$ months after diagnosis despite aggressive surgery, radiation and chemotherapies (2). Therefore, a better understanding of the mechanism through which glioma develops is necessary for efficient and specific inhibition of the progression of this form of cancer.

Potassium $\left(\mathrm{K}^{+}\right)$channels are the most diverse ion channels in the plasma membrane (3). Over the last 10 years, accumulating evidence has indicated that diverse types of $\mathrm{K}^{+}$channels, including voltage-gated, calcium-activated, two-pore domain and inward rectifier $\mathrm{K}^{+}$channels, are overexpressed in a number of tumor types, such as prostate, colon and breast (4-6). Most previous studies have demonstrated that, in addition to controlling physiological parameters, $\mathrm{K}^{+}$channels also play important roles in the onset, proliferation and malignant progression of various types of cancer (7). However, mammalian cells constitutively express an array of various types of $\mathrm{K}^{+}$channels. Although most previous studies have described the expression of a particular type of $\mathrm{K}^{+}$channel in a cancer cell line and have correlated the expression and functional activity of the channel with proliferation, it is not clear to what degree these individual $\mathrm{K}^{+}$channels contribute to proliferation or whether a specific association exists between particular $\mathrm{K}^{+}$channel subtypes and proliferation. Moreover, the mechanisms by which these $\mathrm{K}^{+}$ channels facilitate cell proliferation remain obscure.

Increasing evidence has demonstrated that a variety of $\mathrm{K}^{+}$ channels, such as voltage-gated $\mathrm{K}^{+}$channels $\left(\mathrm{K}_{\mathrm{V}}\right)$, calciumactivated $\mathrm{K}^{+}$channels $\left(\mathrm{K}_{\mathrm{Ca}}\right)$ and ATP-sensitive $\mathrm{K}^{+}$channels $\left(\mathrm{K}_{\mathrm{ATP}}\right)(8-10)$, are overexpressed in glioma biopsies and cultured cells. A previous study found a correlation between the activity of $\mathrm{K}_{\text {АTP }}$ channels and proliferation of glioma cells and xenografted tumors (8). However, it remains uncertain whether other $\mathrm{K}^{+}$channels are also proliferative molecules in glioma cells. Identification of $\mathrm{K}^{+}$channels that play a role in glioma growth may provide novel therapeutic targets. In the present study, we attempted to identify $\mathrm{K}^{+}$channels that affect the growth of human glioma U87-MG cells in vitro and in vivo. Using a variety of $\mathrm{K}^{+}$channel blockers and openers, we found that $\mathrm{K}_{\mathrm{V}}$ and $\mathrm{K}_{\mathrm{ATP}}$ channels play roles in controlling cell proliferation and tumorigenesis, whereas other $\mathrm{K}^{+}$channel subtypes do not. We also analyzed the mechanism of action of $\mathrm{K}^{+}$channels in cell proliferation by studying the relationship between $\mathrm{K}^{+}$channel activities and $\mathrm{Ca}^{2+}$ entry with the use of 
a fluorescent cytosolic $\mathrm{Ca}^{2+}$ assay. Our results demonstrated that $\mathrm{K}_{\mathrm{V}}$ and $\mathrm{K}_{\mathrm{ATP}}$ channels may affect cell proliferation by modulating $\mathrm{Ca}^{2+}$ influx.

\section{Materials and methods}

Chemicals and drug preparations. Tetraethylammonium (TEA), 4-aminopyridine (4-AP), glibenclamide, phloretin, 3-(4,5-dimethylthiazol-2-yl)-2,5-diphenyltetrazolium bromide (MTT), diazoxide, iberiotoxin, tetrodotoxin (TTX) and propidium iodide (PI) were obtained from Sigma Chemical Co. (St. Louis, MO, USA). RPMI-1640 medium and fetal bovine serum (FBS) were obtained from Invitrogen Life Technologies (Carlsbad, CA, USA). The Annexin V-fluorescein isothiocyanate/propidium iodide (Annexin V-FITC/PI) apoptosis detection kit was procured from Antgene Biotech (Wuhan, China). RNase A was purchased from Fermentas International Inc. (Burlington, Ontario, Canada). All other chemicals were of standard analytical grade.

Cell culture. The human glioma cell line U87-MG was purchased from the American Type Culture Collection (ATCC, Manassas, VA, USA) and grown in RPMI-1640 supplemented with $10 \%$ FBS and 100 units of penicillin/streptomycin in $5 \% \mathrm{CO}_{2}$ at $37^{\circ} \mathrm{C}$. The cells were passaged every 3 days and maintained in exponential growth to $\sim 80 \%$ confluency for later experiments.

MTT proliferation assay. A modified MTT assay was used to examine the effect on cell proliferation. Briefly, cells were seeded in a 96-well plate at 5,000 cells/well and incubated overnight. After drug treatment for $48 \mathrm{~h}, 20 \mu \mathrm{l}$ of MTT solution $(5 \mathrm{mg} / \mathrm{ml})$ was added to each well, and the samples were incubated for an additional $4 \mathrm{~h}$. Subsequently, the supernatant was removed, and the cells were dissolved in $150 \mu \mathrm{l}$ of DMSO. Finally, absorbance was measured at $570 \mathrm{~nm}$ using a 96-well microplate reader (Thermo Scientific, USA).

Annexin V-FITC/PI apoptosis assay. Cells were double stained using an Annexin V-FITC/PI apoptosis detection kit. Briefly, after exposure to different drugs for $48 \mathrm{~h}$, the cells were harvested, washed twice with cold PBS and resuspended in Annexin V binding buffer. Then, $5 \mu 1$ of FITC-labeled Annexin $\mathrm{V}$ and $5 \mu 1$ of PI were added. The cells were incubated for $15 \mathrm{~min}$ at room temperature in the dark with gentle oscillation. After the addition of $200 \mu \mathrm{l}$ of binding buffer to each tube, the cells were analyzed within $1 \mathrm{~h}$ using a flow cytometer (Becton-Dickinson, USA).

Cell cycle assay. Cells were detached by trypsinization, seeded at $5 \times 10^{5}$ cells/well in a 6 -well plate and incubated overnight. The cells were then treated with various drugs at different concentrations. Subsequently, the cells were harvested into cold PBS at different time points, fixed in ice-cold $70 \%$ ethanol and stored at $4^{\circ} \mathrm{C}$ overnight for subsequent cell cycle analysis. Fixed cells were washed twice with PBS and resuspended in $1 \mathrm{ml}$ of the staining reagents $(100 \mu \mathrm{g} / \mathrm{ml}$ RNase A and $50 \mu \mathrm{g} / \mathrm{ml}$ PI). The samples were incubated in the dark for $30 \mathrm{~min}$, and the distribution of cells in the various phases of the cell cycle was measured by flow cytometry.
$\left[\mathrm{Ca}^{2+}\right]_{i}$ measurements. Cells were grown overnight, washed twice with Hank's balanced salt solution (HBSS) and loaded with $1 \mu \mathrm{mol} / 1$ Fluo3-AM for $30 \mathrm{~min}$ in the dark at room temperature. Then cells were washed twice with $\mathrm{Ca}^{2+}$-free HBSS, re-suspended in $\mathrm{Ca}^{2+}$-free HBSS and incubated at room temperature for $20 \mathrm{~min}$ in the dark. When appropriate, the cells were pretreated with $\mathrm{K}^{+}$channel blockers or openers for $5 \mathrm{~min}$ before the initiation of $\mathrm{Ca}^{2+}$ influx. $\mathrm{Ca}^{2+}$ influx was measured as changes in fluorescent signals, which were recorded using a fluorescence microscope (Olympus, Japan) and analyzed using Matlab software.

In vivo therapy experiments. To further verify the antiproliferative efficacies of $\mathrm{K}^{+}$channel blockers, an in vivo experiment was performed using 6- to 8-week old nude mice. The nude mice were randomly divided into control and treated groups. The treated groups were subcutaneously injected with a suspension of $5 \times 10^{6} \mathrm{U} 87-\mathrm{MG}$ cells with $4-\mathrm{AP}(5 \mathrm{mmol} / \mathrm{l})$, TEA $(20 \mathrm{mmol} / \mathrm{l})$ or glibenclamide $(200 \mu \mathrm{mol} / \mathrm{l})$, and mice in the control group were injected with a suspension of $5 \times 10^{6}$ cells with $0.01 \mathrm{~mol} / 1$ PBS (8). Tumor size was measured every 3 days and tumor volume was determined by calculating (length $\mathrm{x}$ width) ${ }^{2} / 2$. At the end of the experiment, tumors were excised and weighed. A tumor growth curve was plotted according to the tumor volume, and the inhibitory rates of tumor growth were calculated according to the tumor weight. All procedures were performed in accordance with the National Institutes of Health Guide for the Care and Use of Laboratory Animals.

Electrophysiological assay. Membrane currents were recorded using a whole-cell voltage clamp and borosilicate glass pipettes (outer diameter, $1.5 \mathrm{~mm}$; direct current resistance, 3-6 MS) constructed using a two-step puller (P-97; Sutter, USA). To investigate the $\mathrm{K}_{\mathrm{V}}$ currents, the pipette solution consisted of (in mmol/l) KCl 140, $\mathrm{MgCl}_{2}$ 2.5, HEPES 10, EGTA 11 and ATP 5 and the pH was adjusted to 7.2 (11). To investigate the $\mathrm{K}_{\mathrm{ATP}}$ currents, the micropipettes were filled with (in mmol/l) $\mathrm{KCl} 140, \mathrm{MgCl}_{2}$ 1, ATP 0.01, EGTA-KOH 5 and HEPES-KOH 5 and the $\mathrm{pH}$ was adjusted to 7.3 (12). The cells were bathed in an extracellular solution containing (in $\mathrm{mmol} / \mathrm{l}$ ) $\mathrm{NaCl} 135, \mathrm{KCl} 5.4, \mathrm{MgCl}_{2} 1.0, \mathrm{NaH}_{2} \mathrm{PO}_{4} 0.33, \mathrm{CaCl}_{2} 1.8$, HEPES 10 and D-glucose 10 with $1 \mu \mathrm{mol} / 1$ TTX. The osmolarity was adjusted to $330 \mathrm{mOsm} / 1$ with sucrose and the $\mathrm{pH}$ was adjusted to 7.4. Whole-cell patch clamp recordings were performed at room temperature using a patch clamp amplifier (Axon-200B) (13). Adjustments of capacitance compensation and series resistance compensation were performed before the membrane currents were recorded. The membrane currents were filtered at $10 \mathrm{kHz}(-3 \mathrm{~dB})$ and the data were processed using Clampfit (Axon, USA).

Statistical analysis. The data are expressed as the means \pm standard error ( \pm SE). Statistical significance was assessed using analysis of variance (ANOVA). P-values of $<0.05$ were considered to indicate statistically significant results.

\section{Results}

Effects of $\mathrm{K}^{+}$channel blockers and openers on cell proliferation. To identify the $\mathrm{K}^{+}$channels that affect U87-MG cell prolifera- 

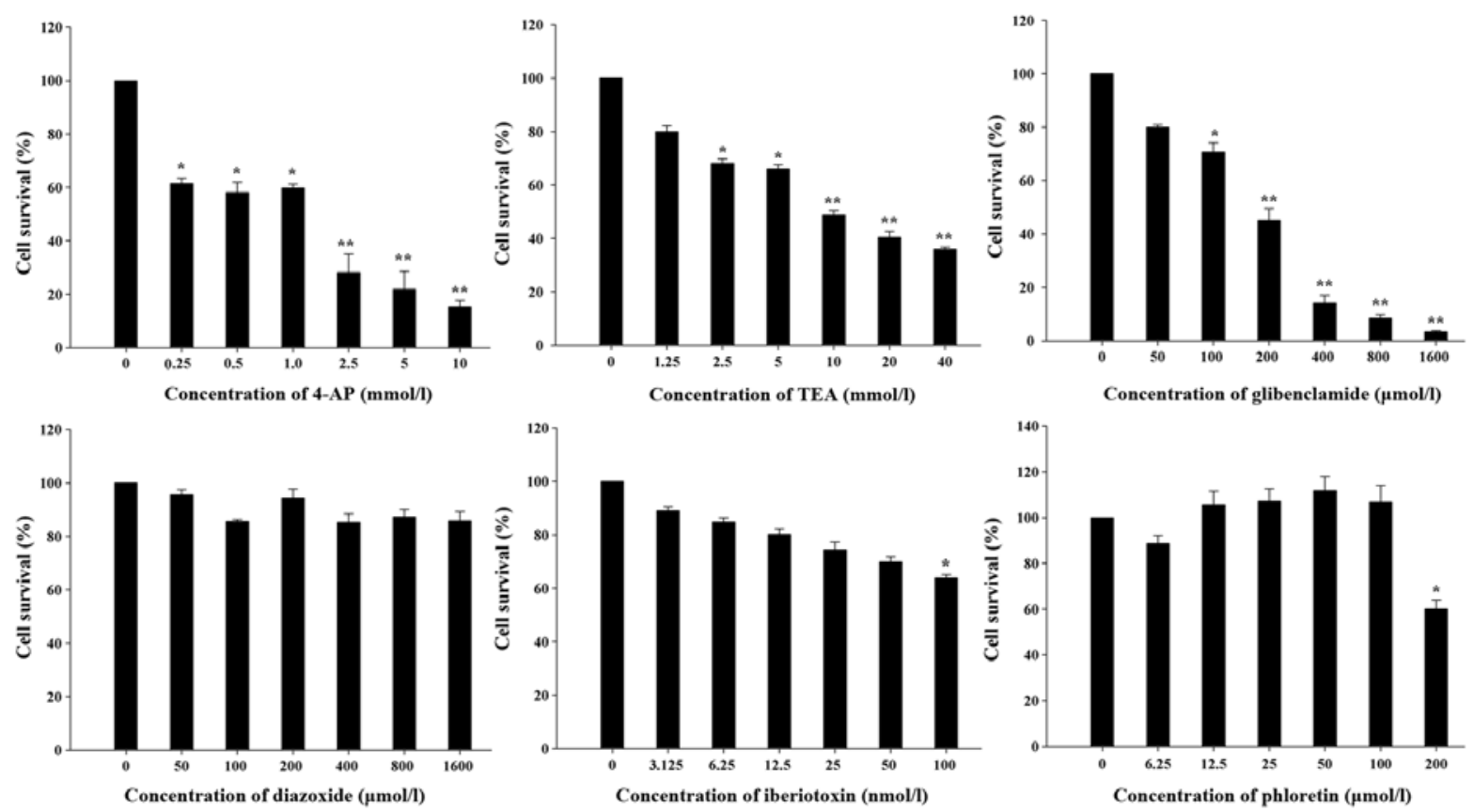

Figure 1. Effects of $\mathrm{K}^{+}$channel blockers and openers on the proliferation of U87-MG cells. U87-MG cells were plated at 5,000 cells/well and treated with the indicated concentrations of the tested $\mathrm{K}^{+}$channel blockers and openers for $48 \mathrm{~h} .{ }^{*} \mathrm{P}<0.05$ and ${ }^{* *} \mathrm{P}<0.01$ when compared to the group treated with a solvent control. $\mathrm{K}^{+}$channel, potassium channel.

tion, we used a variety of $\mathrm{K}^{+}$channel blockers and openers and an MTT assay was used to determine the number of live cells remaining after the drug treatment. Among the blockers, 4-AP and TEA are transient outward and delayed rectifier $\mathrm{K}_{\mathrm{V}}$ channel blockers, respectively (14), whereas glibenclamide is a specific blocker of $\mathrm{K}_{\mathrm{ATP}}$ channels, and iberiotoxin is a specific $\mathrm{K}_{\mathrm{Ca}}$ channel blocker. As shown in Fig. 1, cell proliferation was significantly inhibited by 4-AP and TEA in a dose-dependent manner and glibenclamide also significantly decreased the U87-MG cell number. However, $100 \mathrm{nmol} / \mathrm{l}$ iberiotoxin, a concentration that completely blocks $\mathrm{K}_{\mathrm{Ca}}$ channels (15), only moderately inhibited U87-MG cell proliferation. Meanwhile, diazoxide, an opener of $\mathrm{K}_{\mathrm{ATP}}$ channels and phloretin, an opener of $\mathrm{K}_{\mathrm{Ca}}$ channels, had no significant effects on cell proliferation. Taken together, these data reveal that $\mathrm{K}_{\mathrm{V}}$ and $\mathrm{K}_{\mathrm{ATP}}$ channels but not $\mathrm{K}_{\mathrm{Ca}}$ channels have important roles in the proliferation of U87-MG cells.

Effects of $K^{+}$channel blockers and openers on the cell cycle distribution. To elucidate the mechanisms through which $\mathrm{K}^{+}$channels influence the proliferation of glioma cells, flow cytometry was performed to investigate whether the U87-MG cell cycle may be influenced by various $\mathrm{K}^{+}$channel blockers or openers. As shown in Fig. 2A and B, the percentage of U87-MG cells in the $G_{0} / G_{1}$ phase was significantly enhanced after exposure to 4-AP, TEA and glibenclamide for $48 \mathrm{~h}$, whereas the percentage of cells in the $S$ phase was markedly reduced. Iberiotoxin had no obvious effect on the U87-MG cell cycle at a concentration of $25 \mathrm{nmol} / \mathrm{l}$. Meanwhile, activating $\mathrm{K}_{\mathrm{ATP}}$ channels with diazoxide and activating $\mathrm{K}_{\mathrm{Ca}}$ channels with phloretin increased the percentage of U87-MG cells in the $\mathrm{S}$ phase. These results were consistent with previous reports (16) that $\mathrm{K}^{+}$channels are believed to facilitate progression through $\mathrm{G}_{1} / \mathrm{S}$ checkpoint.
Effects of $K^{+}$channel blockers and openers on cell apoptosis. To determine whether the reduction in cell viability caused by $\mathrm{K}^{+}$ channel blockers was related to apoptotic cell death, the effects of different $\mathrm{K}^{+}$channel blockers and openers on U87-MG cell apoptosis were studied using Annexin V-FITC/PI staining. As illustrated in Fig. 2C, the percentage of Annexin V-FITCpositive apoptotic cells was increased by adding 4-AP or glibenclamide to the U87-MG cells $(5.1 \pm 0.8 \%$ of control, $44.7 \pm 3.8 \%$ of $5 \mathrm{mmol} / \mathrm{l} 4-\mathrm{AP}$ and $18.3 \pm 1.32 \%$ of $200 \mu \mathrm{mol} / 1$ glibenclamide). However, 4-AP only slightly increased necrosis, whereas glibenclamide induced noticeable necrosis $(1.8 \pm 0.26 \%$ of control, $3.2 \pm 0.26 \%$ of $5 \mathrm{mmol} / \mathrm{l} 4-\mathrm{AP}$ and $24.8 \pm 3.08 \%$ of $200 \mu \mathrm{mol} / 1$ glibenclamide). In contrast, at some of the tested concentrations, treatment with TEA, iberiotoxin, phloretin or diazoxide for $48 \mathrm{~h}$ had no apparent effect on cell apoptosis.

Effects of $\mathrm{K}^{+}$channel blockers and openers on $\mathrm{Ca}^{2+}$ influx. To further explore the mechanism of $\mathrm{K}^{+}$channel involvement in U87-MG cell proliferation, we examined the effects of different $\mathrm{K}^{+}$channel blockers and openers on $\mathrm{Ca}^{2+}$ influx. $\mathrm{Ca}^{2+}$ influx was induced by the addition of $0.5 \mathrm{mmol} / \mathrm{l} \mathrm{CaCl}_{2}$ to the bathing medium $\left(\mathrm{Ca}^{2+}\right.$-free $\left.\mathrm{HBSS}\right)$, which caused a rapid increase in cytosolic $\mathrm{Ca}^{2+}$ to a level that was sustained for several minutes. As shown in Fig. 3, 4-AP (5 mmol/l) and glibenclamide (200 $\mu \mathrm{mol} / \mathrm{l})$ nearly abolished the increase in $\left[\mathrm{Ca}^{2+}\right]_{\mathrm{i}}$ induced by exogenously applied $\mathrm{Ca}^{2+}(\mathrm{P}<0.01)$, and TEA $(20 \mathrm{mmol} / \mathrm{l})$ reduced the peak $\mathrm{Ca}^{2+}$ response by $8.5 \pm 0.5 \%(\mathrm{P}<0.05)$, indicating that $\mathrm{K}_{\mathrm{V}}$ and $\mathrm{K}_{\mathrm{ATP}}$ channels may modulate $\mathrm{Ca}^{2+}$ influx into glioma cells and subsequently modulate the proliferation and apoptosis of these cells. Iberiotoxin $(25 \mathrm{nmol} / \mathrm{l})$ decreased the peak $\mathrm{Ca}^{2+}$ response by $2.1 \pm 0.1 \%$, which was not significant when compared with the control cells $(\mathrm{P}>0.05)$. 


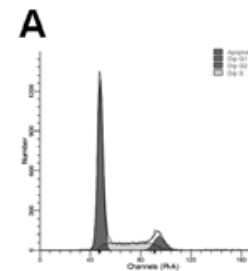

Control

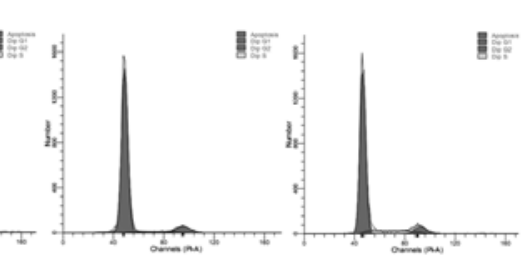

4-AP $5 \mathrm{mmol} / \mathrm{l}$
TEA $20 \mathrm{mmol} / \mathrm{l}$

\section{B}

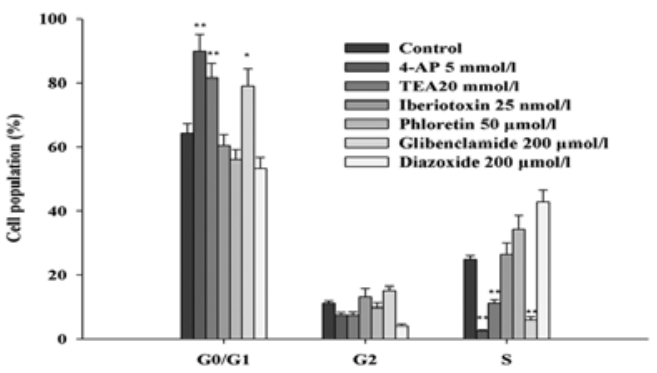

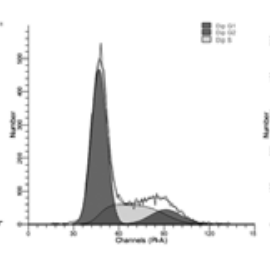

BTX $25 \mathrm{nmol} / \mathrm{l}$

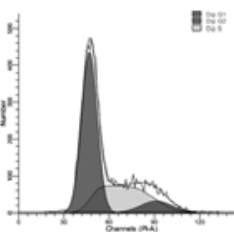

Phl $50 \mu \mathrm{mol} / \mathrm{l}$

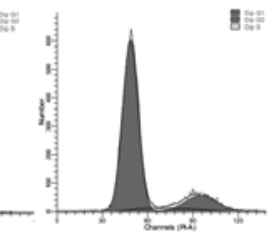

Gli $200 \mu \mathrm{mol} / \mathrm{l}$

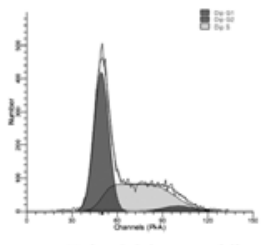

Dia $200 \mu \mathrm{mol} / \mathrm{l}$

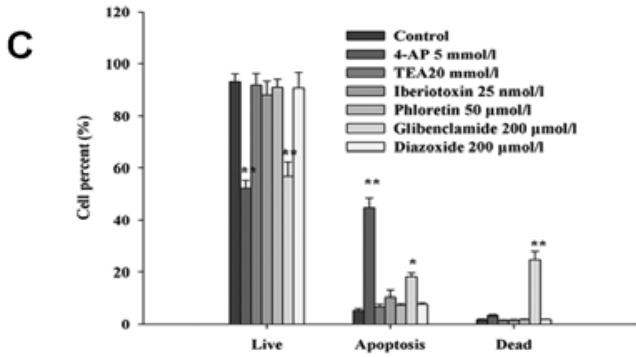

Figure 2. Cell cycle distribution and analysis of apoptosis in U87-MG cells treated with $\mathrm{K}^{+}$channel blockers and openers. (A) U87-MG cells were treated with $\mathrm{K}^{+}$channel blockers or openers for $48 \mathrm{~h}$ at the indicated concentrations, and the cell cycle distribution was determined by flow cytometry after PI staining. (B) Quantitative analysis of the cell population in the different phases of the cell cycle. (C) U87-MG cells were treated with $\mathrm{K}^{+}$channel blockers or openers for $48 \mathrm{~h}$ at the indicated concentrations, labeled with both Annexin V-FITC and PI and subsequently assessed for apoptosis by flow cytometry. 4-AP, 4-aminopyridine; TEA, tetraethylammonium; IBTX, iberiotoxin; Phl, phloretin; Gli, glibenclamide; Dia, diazoxide. " $\mathrm{P}<0.05$ and ${ }^{* *} \mathrm{P}<0.01$ when compared to the control. $\mathrm{K}^{+}$channel, potassium channel.

A

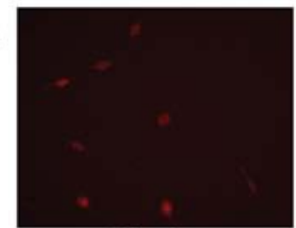

Blank

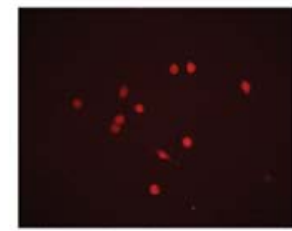

Glibenclamide $200 \mu \mathrm{mol} /$

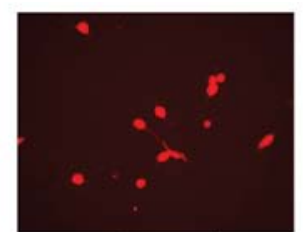

Control

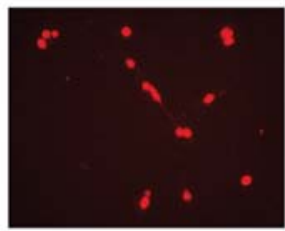

Diazoxide $200 \mu \mathrm{mol} /$

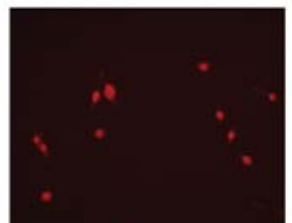

4-AP $5 \mathrm{mmol} / 1$

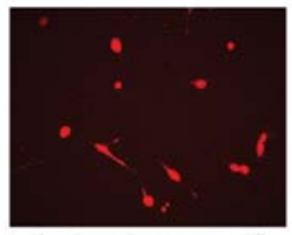

Iberiotoxin $25 \mathrm{nmol} / \mathrm{l}$

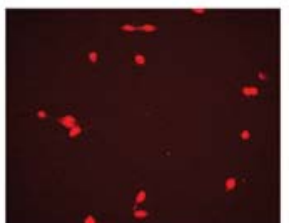

TEA $20 \mathrm{mmol} / 1$

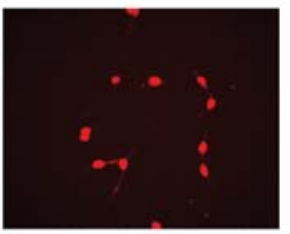

Phloretin $50 \mu \mathrm{mol} / 1$

B

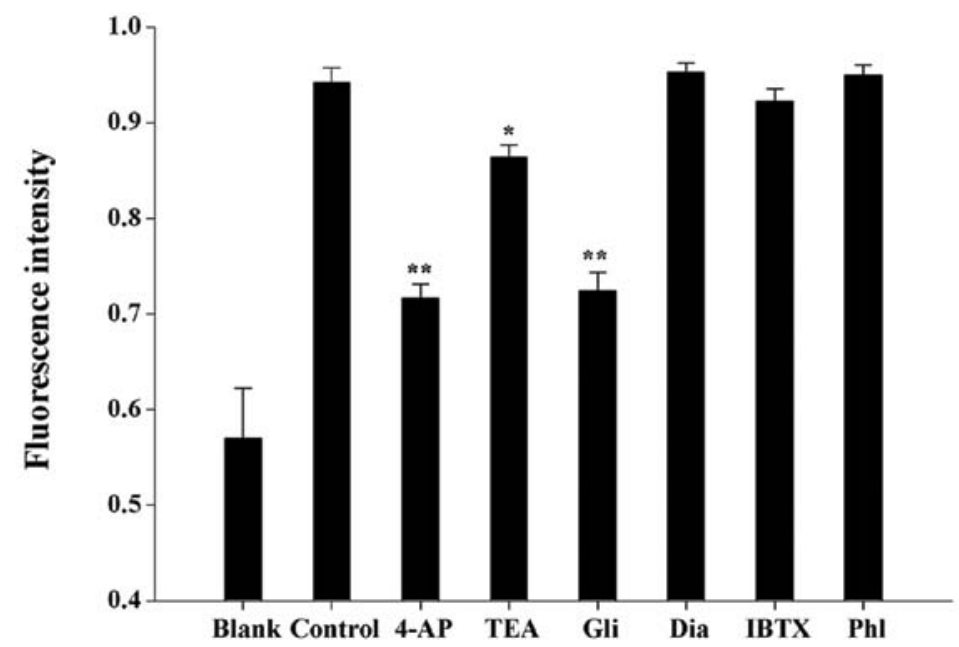

Figure 3. Effects of $\mathrm{K}^{+}$channel blockers and openers on the increase in $\left[\mathrm{Ca}^{2+}\right]_{\mathrm{i}}$ induced by exogenously applied $\mathrm{Ca}^{2+}$. (A) Cells were placed in Ca ${ }^{2+}-\mathrm{free} \mathrm{HBSS}$ with or without blockers. Blank, cells were incubated with $\mathrm{Ca}^{2+}$-free HBSS. Control, $\mathrm{Ca}^{2+}$ influx was induced by adding $0.5 \mathrm{mmol} / 1 \mathrm{CaCl}_{2}$ to $\mathrm{Ca}^{2+}$-free HBSS. (B) The results of $\mathrm{Ca}^{2+}$ influx were analyzed using Matlab software and $\left[\mathrm{Ca}^{2+}\right] \mathrm{i}$ was determined based on the fluorescence intensity. 4-AP, 4-aminopyridine; TEA, tetraethylammonium; Gli, glibenclamide; Dia, diazoxide; IBTX, iberiotoxin; Phl, phloretin. ${ }^{*} \mathrm{P}<0.05$ and ${ }^{* *} \mathrm{P}<0.01$ when compared to the control. $\mathrm{K}^{+}$channel, potassium channel; HBSS, Hank's balanced salt solution. 

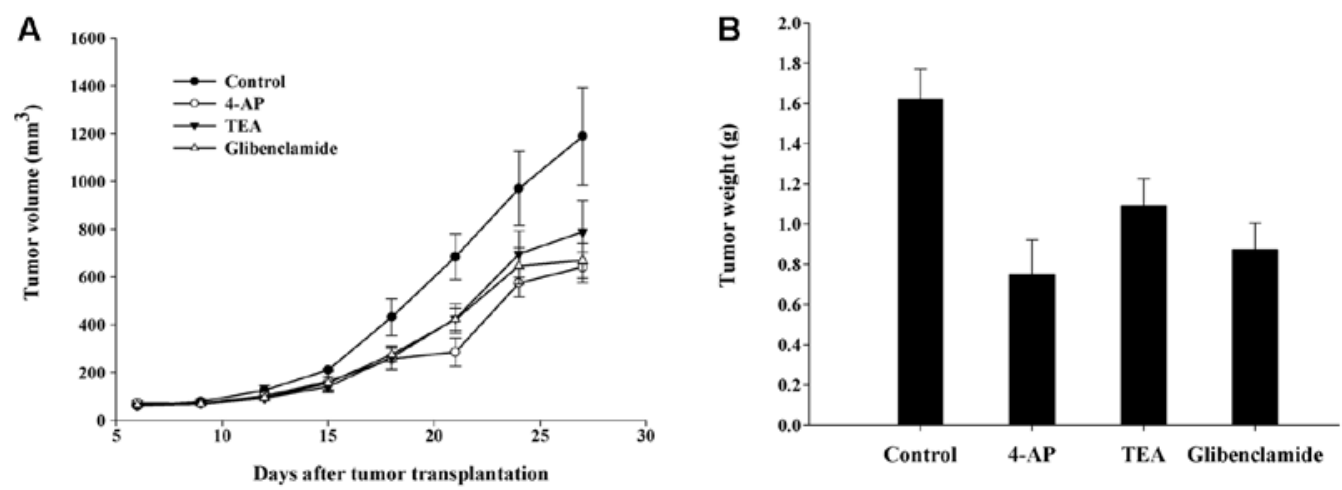

Figure 4. $\mathrm{K}_{\mathrm{V}}$ and $\mathrm{K}_{\mathrm{ATP}}$ channels influence tumor development in nude mice. (A) Suspensions of U87-MG cells with 4-AP (5 mmol/1), TEA (20 mmol/1) or glibenclamide ( $200 \mu \mathrm{mol} / \mathrm{l})$ were injected into the flanks of nude mice. Tumor volume was measured every 3 days, and a growth curve was plotted according to tumor volume. (B) Actual tumor weights at the time of sacrifice were measured. No obvious toxic effects were observed in any of the groups during the experiment. ${ }^{*} \mathrm{P}<0.05$ and ${ }^{* *} \mathrm{P}<0.01$ when compared to the control. $\mathrm{K}_{\mathrm{v}}$, voltage-gated $\mathrm{K}^{+}, \mathrm{K}_{\mathrm{ATP}}$, ATP-sensitive $\mathrm{K}^{+} ; 4$-AP, 4-aminopyridine; TEA, tetraethylammonium.

Therapeutic efficacy of $K^{+}$channel blockers. To provide direct evidence that $\mathrm{K}_{\mathrm{V}}$ or $\mathrm{K}_{\mathrm{ATP}}$ channels are responsible for tumor development, the antitumor activities of $\mathrm{K}_{\mathrm{V}}$ or $\mathrm{K}_{\mathrm{ATP}}$ channel blockers were investigated in nude mice with established human glioma U87-MG xenografts. As shown in Fig. 4A, U87 xenografts grew rapidly in mice, and the tumor size in the control group reached $1189.2 \pm 203.3 \mathrm{~mm}^{3}$ over the duration of the experiment (27 days). Statistically, there were significant differences in both tumor volume and weight between the control and the treated groups. Mice treated with 4-AP at $5 \mathrm{mmol} / \mathrm{l}$ and glibenclamide at $200 \mu \mathrm{mol} / \mathrm{l}$ showed inhibition rates of 46.2 and $43.8 \%$, respectively, which were significant $(\mathrm{P}<0.01)$ when compared with the control. TEA at $20 \mathrm{mmol} / \mathrm{l}$ suppressed tumor growth by $33.7 \%(\mathrm{P}<0.05)$. The actual tumor weights at the time of sacrifice are shown in Fig. 4B. No obvious toxic effects were observed in any of the groups during the experiment. These results suggest that $\mathrm{K}_{\mathrm{V}}$ and $\mathrm{K}_{\mathrm{ATP}}$ channels play important roles in glioma development in vivo.

Effects of $\mathrm{K}^{+}$channel blockers on $\mathrm{K}^{+}$currents. To determine whether $\mathrm{K}^{+}$channel blockers inhibits cell proliferation and tumorigenesis via blockage of whole-cell $\mathrm{K}^{+}$currents, we next studied the dose-dependent effects of these three blockers on $\mathrm{K}_{\mathrm{V}} / \mathrm{K}_{\text {ATP }}$ currents in U87-MG cells. Representative recordings of the $\mathrm{K}_{\mathrm{V}}$ currents (transient and persistent $\mathrm{K}^{+}$currents) were evoked with a step-up depolarization protocol. Briefly, the membrane potential was pre-hyperpolarized from $-50 \mathrm{mV}$ to $-110 \mathrm{mV}$ for $100 \mathrm{msec}$, depolarized from -50 to $+60 \mathrm{mV}(10 \mathrm{mV}$ increment/step, duration $200 \mathrm{msec}$ ) and subsequently restored to the original depolarizing potential of $-50 \mathrm{mV}$ (Fig. 5A). Depolarizing the voltage from -110 to $-50 \mathrm{mV}$ and maintaining the level of $-50 \mathrm{mV}$ for $100 \mathrm{msec}$ inactivated transient $\mathrm{K}^{+}$ currents and a further depolarization voltage step from -50 to $+60 \mathrm{mV}$ evoked persistent $\mathrm{K}^{+}$currents (Fig. 5B). The transient component (Fig. 5C) was then visualized in isolation using point-by-point subtraction of the persistent component (as shown in Fig. 5B) from the total outward current (as shown in Fig. 5A). As shown in Fig. 5D, 5 mmol/l TEA remarkably inhibited the persistent outward currents and the persistent component was reduced completely after the application of TEA (40 mmol/l). Meanwhile, 4-AP ( $1 \mathrm{mmol} / \mathrm{l})$ markedly suppressed the transient outward current and 4-AP (10 mmol/l $)$ completely and reversibly blocked the transient components in each cell examined (Fig. 5E).

To examine the effect of glibenclamide on $\mathrm{K}_{\mathrm{ATP}}$ currents, $\mathrm{K}_{\mathrm{ATP}}$ currents were activated by using standard whole cell recording with a pipette solution containing only $10 \mathrm{mmol} / 1$ ATP (12). The membrane potential was normally held at $-40 \mathrm{mV}$ and the currents were evoked by a series of $400 \mathrm{msec}$ depolarizing and hyperpolarizing current steps $(-100 \mathrm{mV}$ to $+80 \mathrm{mV}$ in $20 \mathrm{mV}$ steps, Fig. 5F). As shown in Fig. 5G, the whole-cell $\mathrm{K}^{+}$currents observed with low intracellular ATP were inhibited by extracellular glibenclamide $(300 \mu \mathrm{mol} / \mathrm{l})$. These data suggest that these three $\mathrm{K}^{+}$channel blockers have the same working concentration range for inhibiting $\mathrm{K}_{\mathrm{V}} / \mathrm{K}_{\text {ATP }}$ currents, cell proliferation and tumor growth, indicating that the effects of 4-AP, TEA and glibenclamide are indeed mediated by blockage of $\mathrm{K}^{+}$channels.

\section{Discussion}

As a crucial cellular function, cell growth is strictly controlled by several independent mechanisms. Since the pioneering study in lymphocytes by DeCoursey et al (17), accumulating evidence has indicated that $\mathrm{K}^{+}$channels are relevant players in the control of this process. Diverse types of $\mathrm{K}^{+}$channels have been shown to be overexpressed in tumorous tissues and the roles of $\mathrm{K}^{+}$channels in tumor cell growth have been demonstrated $(9,15)$. However, the types of $\mathrm{K}^{+}$channels involved in this process vary $(18,19)$. For example, $\mathrm{K}_{\mathrm{Ca}}$ channels were found to be involved in prostate (5), gastric (20) and colorectal cancer (4). In other tumors, proliferation was supported by $\mathrm{K}_{\mathrm{ATP}}$ channels or two-pore (2P)-domain channels $(21,22)$. Nevertheless, in the majority of cancer cells, $K_{V}$ channels were correlated with proliferation $(7,16,23)$. It remains unknown why different types of $\mathrm{K}^{+}$channels induce proliferation in different cancer models.

In the present study, we showed that 4-AP, TEA and glibenclamide significantly suppressed cell proliferation in vitro. The percentage of U87-MG cells in the $\mathrm{G}_{0} / \mathrm{G}_{1}$ phase was also significantly enhanced after exposure to 4-AP, TEA or glibenclamide for $48 \mathrm{~h}$. On the other hand, diazoxide and phloretin increased the percentage of cells in the $\mathrm{S}$ phase. These findings, together with previous reports $(8,24)$, demonstrate that 
A

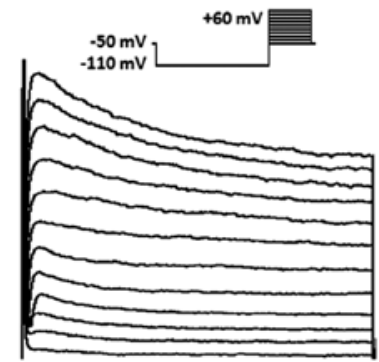

B

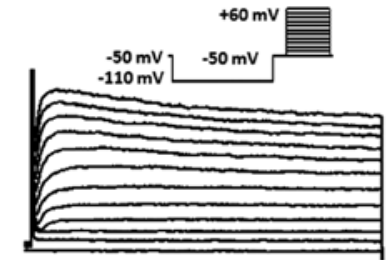

C

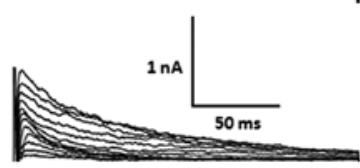

low ATP
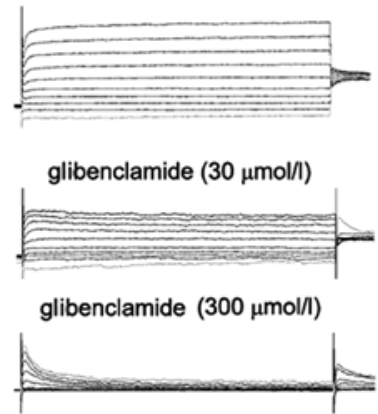
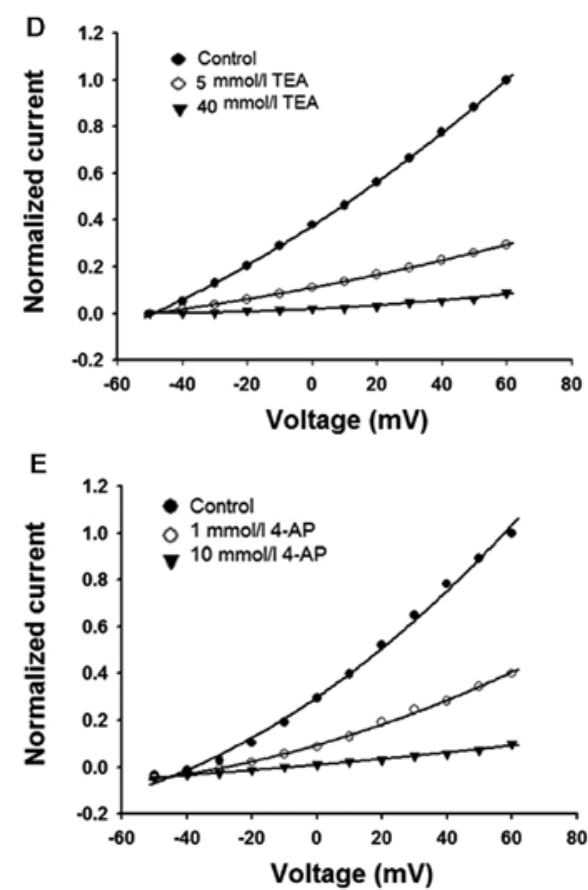

G

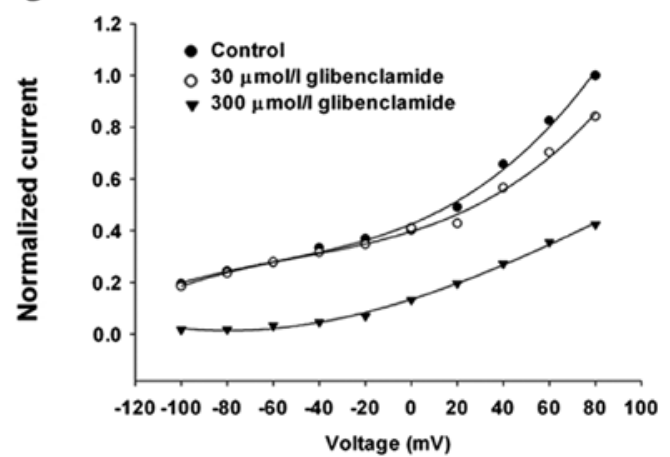

Figure 5. Effects of $\mathrm{K}^{+}$channel blockers and openers on $\mathrm{K}_{\mathrm{v}} / \mathrm{K}_{\mathrm{ATP}}$ currents. (A) Representative traces of total $\mathrm{K}_{\mathrm{V}}$ currents evoked by a voltage depolarizing step. The voltage protocol is shown at the top. (B) The slow persistent currents recorded from the same cell evoked by the depolarization protocol are shown at the top. (C) The fast transient currents obtained by subtracting the persistent currents from the total $\mathrm{K}_{\mathrm{V}}$ currents. (D) TEA suppressed the I-V curve of the slow persistent $\mathrm{K}^{+}$currents. (E) 4-AP suppressed the I-V curve of the fast transient $\mathrm{K}^{+}$currents. (F) $\mathrm{K}_{\mathrm{ATP}}$ currents in U87-MG cells in the absence (low ATP) and presence of glibenclamide $(300 \mu \mathrm{mol} / \mathrm{l})$ were evoked by a series of $400 \mathrm{msec}$ depolarizing and hyperpolarizing current steps $(-100 \mathrm{mV}$ to $+80 \mathrm{mV}$ in $20 \mathrm{mV}$ steps). (G) Glibenclamide suppressed the I-V curve of the $\mathrm{K}_{\mathrm{ATP}}$ currents. $\mathrm{K}^{+}$channel, potassium channel; $\mathrm{K}_{\mathrm{V}}$, voltage-gated $\mathrm{K}^{+}$, $\mathrm{K}_{\text {ATP }}$, ATP-sensitive $\mathrm{K}^{+}$; TEA, tetraethylammonium; 4-AP, 4-aminopyridine.

$\mathrm{K}^{+}$currents are the key determinant of progression through the $\mathrm{G}_{1} / \mathrm{S}$ checkpoint of the cell cycle. In addition, we also found that 4-AP and glibenclamide both significantly increased the percentage of apoptotic cells. In the U87-MG xenograft model in nude mice, 4-AP, TEA and glibenclamide markedly suppressed tumor growth in vivo. Taken together, these results suggest that $\mathrm{K}_{\mathrm{V}}$ and $\mathrm{K}_{\mathrm{ATP}}$ channels are the critical $\mathrm{K}^{+}$channel subtypes for U87-MG glioma growth.

Given the important role of $\mathrm{K}^{+}$channels in tumors, it is necessary to clarify their role in proliferation. One hypothesis is that $\mathrm{K}^{+}$channels keep the resting membrane potential sufficiently polarized to allow the influx of $\mathrm{Ca}^{2+}$ via membrane ion channels (25), implying that blocking $\mathrm{K}^{+}$channels will directly modulate $\mathrm{Ca}^{2+}$ entry in malignant cells. This may be a partial reason for the induction of tumor growth via the abnormal expression of $\mathrm{K}^{+}$channel subtypes since $\mathrm{Ca}^{2+}$ acts as an activator involved in many cellular signal transduction pathways, including the cell growth and mitosis pathways (26). For example, early reports indicate that growth of the colorectal adenocarcinoma cell line DLD-1 and the ovarian cancer cell line A2780 was associated with the regulatory effect of $\mathrm{K}_{\mathrm{V}}$ channels on $\mathrm{Ca}^{2+}$ influx $(24,25)$. Nevertheless, to date, no direct evidence has ever been presented to support the relationship between $\mathrm{K}^{+}$channel activity and $\mathrm{Ca}^{2+}$ ion entry in glioma cells. Here, we found that 4-AP and glibenclamide nearly abolished the increase in $\left[\mathrm{Ca}^{2+}\right]_{\mathrm{i}}$ induced by exogenously added $\mathrm{Ca}^{2+}$. Sine the change in $\left[\mathrm{Ca}^{2+}\right]_{\mathrm{i}}$ may be due to a change in $\mathrm{Ca}^{2+}$ influx from the extracellular medium or an alteration in $\mathrm{Ca}^{2+}$ release from an internal store, we further examined the potential effects of $\mathrm{K}^{+}$channels on the release of $\mathrm{Ca}^{2+}$ from intracellular stores, and we found that $\left[\mathrm{Ca}^{2+}\right]_{\mathrm{i}}$ in U87-MG cells was not affected by $\mathrm{K}^{+}$channel blockers or openers (data not shown). Through these experiments, we established a link between $\mathrm{K}_{\mathrm{V}}$ and $\mathrm{K}_{\mathrm{ATP}}$ channel activities and $\mathrm{Ca}^{2+}$ influx, indicating that modulation of $\mathrm{Ca}^{2+}$ influx may influence the proliferation of U87-MG cells. 
The expression of $\mathrm{K}_{\mathrm{Ca}}$ channels is correlated with glioma malignancy, with higher levels of $\mathrm{K}_{\mathrm{Ca}}$ protein observed in more malignant glioma biopsy samples (27). However, the relationship between $\mathrm{K}_{\mathrm{Ca}}$ channels and glioma cells is controversial. Some recent publications have proposed the idea that $\mathrm{K}_{\mathrm{Ca}}$ channels may have antiproliferative and antitumorigenic properties (28). Other results implicating $\mathrm{K}_{\mathrm{Ca}}$ channels in the control of glioma cell growth have been collected using specific cell growth conditions, such as an elevated extracellular $\mathrm{K}^{+}$concentration (29) or serum deprivation (30). Our data showed that the inhibitory effect of iberiotoxin was only observable at concentrations greatly exceeding those necessary for complete channel blockage (15), and increases in apoptotic cells and cells in the $\mathrm{G}_{0} / \mathrm{G}_{1}$ phase were not clearly observed, suggesting that $\mathrm{K}_{\mathrm{Ca}}$ channels may not play a role in the growth of U87-MG glioma cells in vitro.

Although all the blockers of $\mathrm{K}_{\mathrm{V}}$ and $\mathrm{K}_{\mathrm{ATP}}$ channels tested in this study suppressed glioma cell proliferation and tumor development, it remains unclear whether their effects occur at the concentrations required to block $\mathrm{K}^{+}$channel activities. Electrophysiological results showed that 4-AP, TEA and glibenclamide inhibited cell proliferation and tumor growth in the concentration range required to block $\mathrm{K}_{\mathrm{V}} / \mathrm{K}_{\mathrm{ATP}}$ channel currents, indicating that these $\mathrm{K}^{+}$channel blockers suppress glioma cell proliferation by blocking $\mathrm{K}^{+}$channel activities and providing further support for the roles of $\mathrm{K}_{\mathrm{V}} / \mathrm{K}_{\text {ATP }}$ channels in mediating cell proliferation and tumor growth.

In summary, the present findings provide strong evidence that $\mathrm{K}_{\mathrm{V}}$ and $\mathrm{K}_{\mathrm{ATP}}$ channel blockers inhibit proliferation and tumorigenesis of U87-MG glioma cells. It is likely that $\mathrm{K}^{+}$ channel activities modulate $\mathrm{Ca}^{2+}$ influx into U87-MG cells and therefore affect the proliferation, cell cycle progression and apoptosis of these cells. Further study is needed to define the precise mechanisms responsible for the antiproliferative effects of pharmacological blockers of $K_{V}$ and $K_{\text {ATP }}$ channels. In any case, it is worthwhile to further explore the possibility of using $\mathrm{K}_{\mathrm{V}}$ and $\mathrm{K}_{\mathrm{ATP}}$ channels as new anti-glioma targets in the coming years.

\section{Acknowledgements}

The present study was supported by the Wuhan Science and Technology Foundation (201250499145-31) and Natural Science Foundation of China (81302203).

\section{References}

1. Ru Q, Shang BY, Miao QF, Li L, Wu SY, Gao RJ and Zhen YS: A cell penetrating peptide-integrated and enediyne-energized fusion protein shows potent antitumor activity. Eur J Pharm Sci 47: 781-789, 2012.

2. Van Meir EG, Hadjipanayis CG, Norden AD, Shu HK, Wen PY and Olson JJ: Exciting new advances in neuro-oncology: the avenue to a cure for malignant glioma. CA Cancer J Clin 60: 166-193, 2010.

3. Fiske JL, Fomin VP, Brown ML, Duncan RL and Sikes RA: Voltage-sensitive ion channels and cancer. Cancer Metastasis Rev 25: 493-500, 2006.

4. Spitzner M, Ousingsawat J, Scheidt K, Kunzelmann K and Schreiber R: Voltage-gated $\mathrm{K}^{+}$channels support proliferation of colonic carcinoma cells. FASEB J 21: 35-44, 2007.

5. Abdul M and Hoosein N: Expression and activity of potassium ion channels in human prostate cancer. Cancer Lett 186: 99-105, 2002

6. Zhang L, Zou W, Zhou SS and Chen DD: Potassium channels and proliferation and migration of breast cancer cells. Sheng $\mathrm{Li}$ Xue Bao 61: 15-20, 2009.
7. Le Guennec JY, Ouadid-Ahidouch H, Soriani O, Besson P, Ahidouch A and Vandier C: Voltage-gated ion channels, new targets in anti-cancer research. Recent Pat Anticancer Drug Discov 2: 189-202, 2007.

8. Huang L, Li B, Li W, Guo H and Zou F: ATP-sensitive potassium channels control glioma cell proliferation by regulating ERK activity. Carcinogenesis 30: 737-744, 2009.

9. Abdullaev IF, Rudkouskaya A, Mongin AA and Kuo YH: Calcium-activated potassium channels BK and IK1 are functionally expressed in human gliomas but do not regulate cell proliferation. PLoS One 5: e12304, 2010.

10. Lefranc F, Pouleau HB, Rynkowski M and De Witte O: Voltagedependent $\mathrm{K}^{+}$channels as oncotargets in malignant gliomas. Oncotarget 3: 516-517, 2012.

11. Akamine T, Nishimura Y, Ito K, Uji Y and Yamamoto T: Effects of haloperidol on $\mathrm{K}^{+}$currents in acutely isolated rat retinal ganglion cells. Invest Ophthalmol Vis Sci 43: 1257-1261, 2002.

12. Du Q, Jovanović S, Sukhodub A, Barratt E, Drew E, Whalley KM, Kay V, McLaughlin M, Telfer EE, Barratt CL and Jovanović A: Human oocytes express ATP-sensitive $\mathrm{K}^{+}$channels. Hum Reprod 25: 2774-2782, 2010.

13. Yi CL, Liu YW, Xiong KM, Stewart RR, Peoples RW, Tian X, Zhou L, Ai YX, Li ZW, Wang QW and Li CY: Conserved extracellular cysteines differentially regulate the inhibitory effect of ethanol in rat $\mathrm{P} 2 \mathrm{X}_{4}$ receptors. Biochem Biophys Res Commun 381: 102-106, 2009.

14. Schaarschmidt G, Wegner F, Schwarz SC, Schmidt H and Schwarz J: Characterization of voltage-gated potassium channels in human neural progenitor cells. PLoS One 4: e6168, 2009.

15. Weaver AK, Liu X and Sontheimer H: Role for calcium-activated potassium channels (BK) in growth control of human malignant glioma cells. J Neurosci Res 78: 224-234, 2004.

16. Pardo LA: Voltage-gated potassium channels in cell proliferation. Physiology 19: 285-292, 2004.

17. DeCoursey TE, Chandy KG, Gupta S and Cahalan MD: Voltagegated $\mathrm{K}^{+}$channels in human T lymphocytes: a role in mitogenesis? Nature 307: 465-468, 1984.

18. Pardo LA, Contreras-Jurado C, Zientkowska M, Alves F and Stühmer W: Role of voltage-gated potassium channels in cancer. J Membr Biol 205: 115-124, 2005.

19. Wang Z: Roles of $\mathrm{K}^{+}$channels in regulating tumour cell proliferation and apoptosis. Pflugers Arch 448: 274-286, 2004.

20. Elso CM, Lu X, Culiat CT, Rutledge JC, Cacheiro NL, Generoso WM and Stubbs LJ: Heightened susceptibility to chronic gastritis, hyperplasia and metaplasia in Kcnql mutant mice. Hum Mol Genet 13: 2813-2821, 2004.

21. Patel AJ and Lazdunski M: The $2 \mathrm{P}$-domain $\mathrm{K}^{+}$channels: role in apoptosis and tumorigenesis. Pflugers Arch 448: 261-273, 2004.

22. Klimatcheva $\mathrm{E}$ and Wonderlin WF: An ATP-sensitive $\mathrm{K}^{+}$current that regulates progression through early $\mathrm{G} 1$ phase of the cell cycle in MCF-7 human breast cancer cells. J Membr Biol 171: 35-46, 1999.

23. Asher V, Warren A, Shaw R, Sowter H, Bali A and Khan R: The role of Eag and HERG channels in cell proliferation and apoptotic cell death in SK-OV-3 ovarian cancer cell line. Cancer Cell Int 11: 6, 2011.

24. Zhanping W, Xiaoyu P, Na C, Shenglan W and Bo W: Voltagegated $\mathrm{K}^{+}$channels are associated with cell proliferation and cell cycle of ovarian cancer cell. Gynecol Oncol 104: 455-460, 2007.

25. Yao X and Kwan HY: Activity of voltage-gated $\mathrm{K}^{+}$channels is associated with cell proliferation and $\mathrm{Ca}^{2+}$ influx in carcinoma cells of colon cancer. Life Sci 65: 55-62, 1999.

26. Shen Z, Yang Q and You Q: Research toward potassium channels on tumor progressions. Curr Top Med Chem 9: 322-329, 2009.

27. Jones RD, Kerr DJ, Harnett AN, Rankin EM, Ray S and Kaye SB: A pilot study of quinidine and epirubicin in the treatment of advanced breast cancer. Br J Cancer 62: 133-135, 1990.

28. Fishman MC and Spector I: Potassium current suppression by quinidine reveals additional calcium currents in neuroblastoma cells. Proc Natl Acad Sci USA 78: 5245-5249, 1981.

29. Basrai D, Kraft R, Bollensdorff C, Liebmann L, Benndorf K and Patt S: BK channel blockers inhibit potassium-induced proliferation of human astrocytoma cells. Neuroreport 13: 403-407, 2002.

30. Weiger TM, Colombatto S, Kainz V, Heidegger W, Grillo MA and Hermann A: Potassium channel blockers quinidine and caesium halt cell proliferation in C6 glioma cells via a polyaminedependent mechanism. Biochem Soc Trans 35: 391-395, 2007. 